
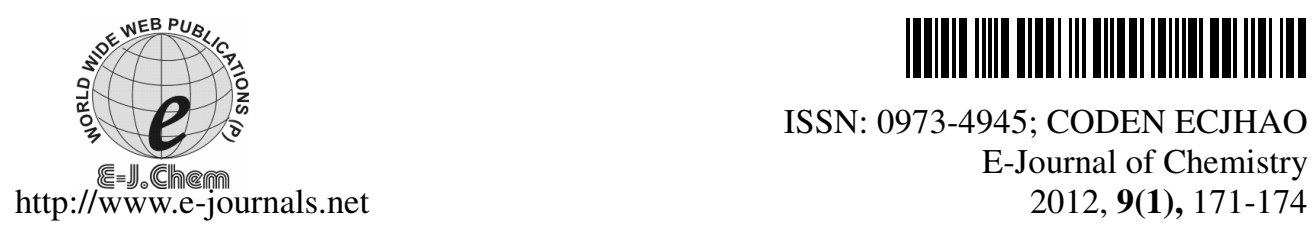

ISSN: 0973-4945; CODEN ECJHAO

E-Journal of Chemistry 2012, 9(1), 171-174

\title{
CdTe Quantum dots Modified by Polyamidoamine Dendrimers for Cell Imaging
}

\author{
JUN'AN LIU ${ }^{\S}$, XIAOLEI WEI ${ }^{\S}$, JIANHUA CAO and HONG JIANG $^{\S *}$ \\ ${ }^{\S}$ College of Science, Huazhong Agricultural University, Wuhan 430070, China \\ College of Animal Sciences \& Technology / College of Veterinary Medicine \\ Huazhong Agricultural University, Wuhan 430070, China \\ jianghong0066@126.com
}

Received 18 June 2011; Accepted 13 August 2011

\begin{abstract}
Water soluble CdTe quantum dots have shown potential as a platform for development of live cell imaging, but their cytotoxicity limits their biological applications. To decrease their cytotoxicity, an approach to modify CdTe quantum dots (QDs) with polyamidoamine (PAMAM) was employed by forming covalent bonds between them. The resultant nanocomposites as a cell imaging bioprobe for live PK15 and their in vitro toxicity were also investigated. The results showed that the prepared nanocomposites were able to enter PK15 cells with good biocompatibility and low cellular toxicity.
\end{abstract}

Keywords: Quantum dots, Dendrimer, Nanocomposites, Luminescence, Cell imaging

\section{Introduction}

Rapid advances in nanotechnology and nanoscience have spurred interests in developing a variety of nanostructure materials. In this context, semiconductor nanoparticles (also known as quantum dots, QDs) are the most promising ones due to their high photochemical stability and size-tunable photoluminescence ${ }^{1}$. QDs have potential applications in optoelectronics, biosensing, biolabelling and cell imaging ${ }^{2,3}$. QDs can be linked to biomaterials such as monoclonal antibodies, peptides, oligonucleotides by self-assembly through noncovalent interactions. However, this linking method has inherent instability drawback under such environmental conditions as low $\mathrm{pH}$, higher temperature etc. Thus, an alternative approach to preparing QDs assemblies by covalent bond is desirable. In addition, the cellular toxicity of QDs is also of great concerns. Therefore how to enhance QDs' stability and biocompatibility and decrease their toxicity in bio-system is a great challenge ${ }^{4}$. 
Polyamidoamine (PAMAM) dendrimers are synthetic spherical macromolecules with well-defined surface, including a core, branches and a lot of terminal groups ${ }^{5}$. Their excellent biocompatibility and low toxicity lead to many potential biological applications ${ }^{6}$. PAMAM dendrimers are small enough to pass into the cell membrane and can be used to deliver substances such as drugs, genetic materials or chemical markers and therefore make them potentially useful for many biological applications ${ }^{7,11}$. This inspired us to prepare PAMAM dendrimers modified CdTe quantum dots to counteract the defects of QDs.

In this paper, we succeeded in preparing the PAMAM dendrimer-modified QDs through covalent binding (Scheme 1) and investigated their biocompatibility and cytotoxicity in PK15 cells. Our results showed that the QDs could enter into PK15 cells and scattered in the cytoplasm with lower cytotoxicity and good biocompatibility.

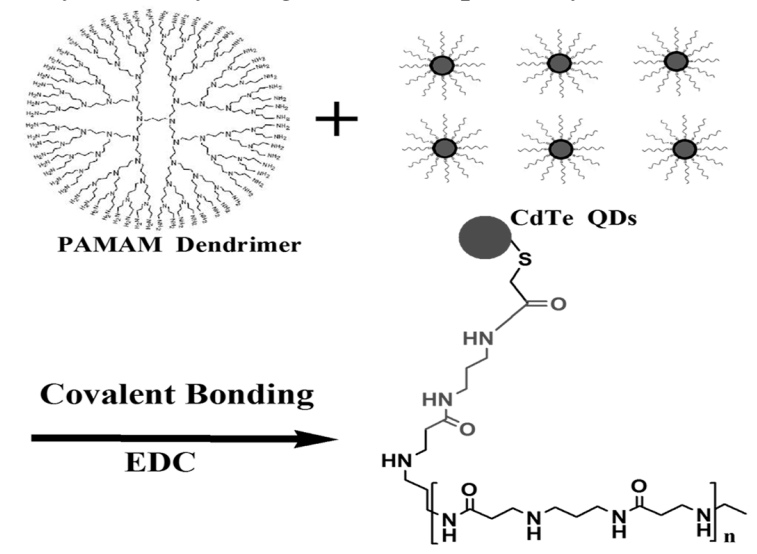

Scheme 1. The synthetic route used to prepare the QDs-dendrimer nanocomposites

\section{Experimental}

Water soluble CdTe QDs solution was prepared as literature with some modification ${ }^{12}$. An aqueous solution of $\mathrm{Cd}^{2+}$ ion and TGA was prepared and $\mathrm{pH}$ was adjusted to 11 . Then, Under vigorous stirring, trisodium citrate, $\mathrm{Na}_{2} \mathrm{TeO}_{3}$, were added in sequence, after stirring 5 min, $\mathrm{NaBH}_{4}$ powder was added under open-air conditions. Typical molar ratio of $\mathrm{Cd}$ :Te:TGA was 2:1:5 in our experiments. The resulting mixture solution was heated to $100{ }^{\circ} \mathrm{C}$ and refluxed to $5 \mathrm{~h}$ for obtaining the red CdTe QDs. The CdTe QDs precipitates were rinsed with ethanol and dried by vacuum oven and then were stored at $4{ }^{\circ} \mathrm{C}$ in dark.

\section{Synthesis of CdTe-PAMAM nanocomposites}

The PAMAM of generation $3.0\left(\mathrm{NH}_{2}\right.$ terminated) were obtained from Sigma Aldrich, China Mainland. In a typical synthesis of CdTe-dendrimer nanocomposites, $3 \mathrm{~mL}$ aqueous solution of CdTe QDs $\left(5.3 \times 10^{-6} \mathrm{M}\right)$ was mixed with $1 \mathrm{~mL}$ dendrimers $\left(7.09 \times 10^{-6} \mathrm{M}\right)$ and $100 \mu \mathrm{L}$ $0.1 \mathrm{mg} \cdot \mathrm{mL}^{-1}$ EDC. The solution was allowed to react at room temperature for $24 \mathrm{~h}$ and dialyzed against the phosphate buffer.

\section{The cell imaging and MTT assay}

The cell imaging

The PK15 cells were plated onto $20 \mathrm{~mm}$ glass coverslips in a 6-well tissue culture plate and were allowed to grow for $24 \mathrm{~h}$ in a DMEM medium supplemented with $10 \%$ FBS and $1 \%$ penicillin streptomycin at $37^{\circ} \mathrm{C}$. The culture medium was then removed, the cells were washed 
three times at $4{ }^{\circ} \mathrm{C}$ using wash buffer (PBS with $1 \mathrm{mM} \mathrm{CaCl}_{2}$ and $1 \mathrm{mM} \mathrm{MgCl}$ ) and fixed 20 min with $4 \%$ paraformaldehyde solution. Then washed three times with PBS and incubated for about 30 min with $200 \mu \mathrm{L}$ CdTe-PAMAM dendrimer nanocomposites. After that the cells were washed three times with cold washing buffer and then immediately subjected to imaging under an inverted Laser scanning confocal microscope (Zeiss LSM 510 META).

\section{MTT assay and cell counting}

Colorimetric MTT (3-[4, 5-dimethylthiazol-2-yl]-2, 5-diphenyl tetrazolium bromide) assays were performed to assess the metabolic activity of cells treated with CdTe-PAMAM nanocomposites. After the treatment, the medium was removed and replaced with serumfree media $(100 \mu \mathrm{L} /$ well $)$. A total of $10 \mu \mathrm{L}$ stock MTT $\left(5 \mathrm{mg} \cdot \mathrm{mL}^{-1}\right)$ was added to each well, and the cells were then incubated for $1 \mathrm{~h}$ at $37{ }^{\circ} \mathrm{C}$. The medium was removed and the cells were lysed with DMSO. The absorbance was measured at $490 \mathrm{~nm}$. Cell number was determined by trypan blue exclusion assay.

\section{Results and Discussion}

\section{Characterization of CdTe-PAMAM nanocomposites}

We successfully prepared fluorescent CdTe-PAMAM dendrimer nanocomposites through covalent bonds by crosslinking agent EDC (Figure 1), then the nanocomposites was characterized by TEM images, photoluminescence (PL) spectra. As shown in Figure 2, transmission electron microscopy images show the good stability and dispersion. Fluorescence emission intensity map shows a slight decrease compared with the quantum dots, but the emission spectrum still shows typical Gaussian distribution (Figure 3).

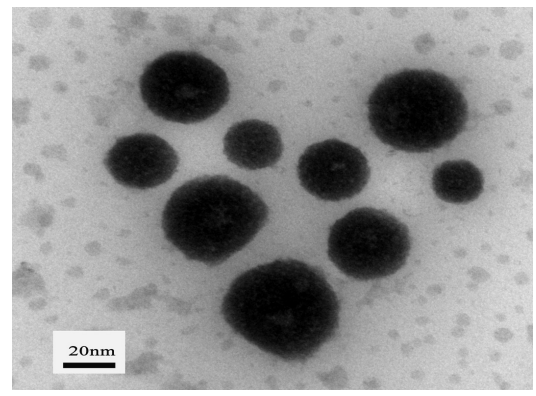

Figure 1. TEM images of CdTe QD-PAMAM nanocomposites

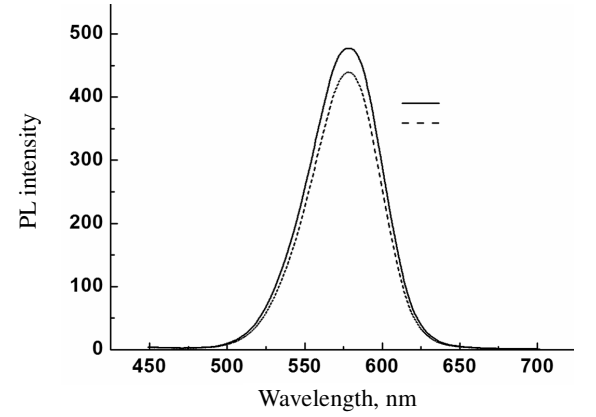

Figure 2. The normalized luminescence spectra of CdTe QDs before (solid line) and after conjugation with dendrimer (dash line)

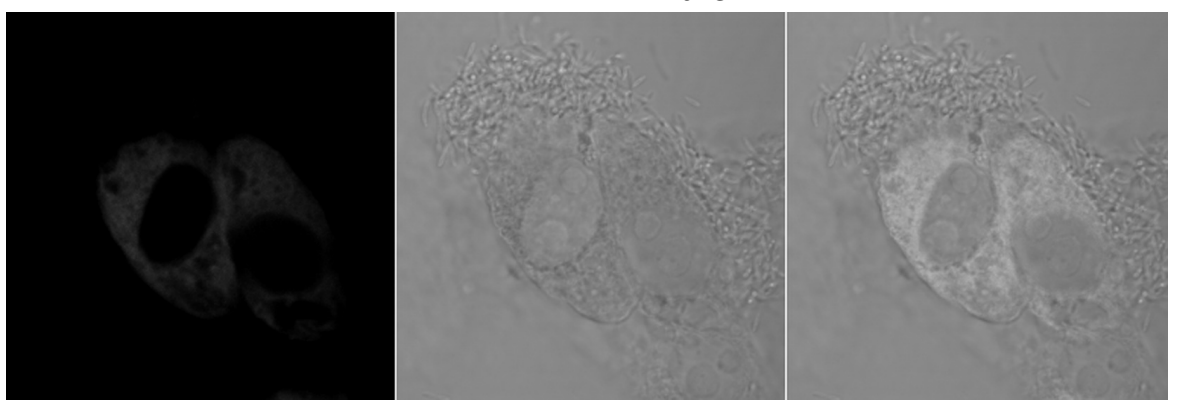

Figure 3. Confocal images of fixed PK15 cells incubated with CdTe-dendrimer nanoprobe 
The left row represents the fluorescence image, the central row represents the phase contrast image and the right row is an overlay of the left and central rows. CdTe-PAMAM dendrimer nanocomposites were dispersed in the cytoplasm.

\section{The cell imaging}

In our study, to evaluate the biocompatibility and cytotoxicity of CdTe-PAMAM dendrimer nanocomposites, we firstly measured the compatibility of as-prepared nanocomposites to PK15 cells. As shown in Figure 4, PK15 cells incubated with CdTe-PAMAM dendrimer nanocomposites, exhibited a strong red color and could not be washed away, which indicated that the CdTe-PAMAM dendrimer nanocomposites could pass into the cell membrane and scattered in the cytoplasm. Then after incubation of PK15 cells with nanocomposites, cell viability was assessed by the MTT assay. The results indicated cell viability was about $75.28 \%$ after $48 \mathrm{~h}$ incubation; while after incubation PK15 cells directly with QDs for $12 \mathrm{~h}$, the cell viability was only about $25.23 \%$, which proved that the CdTePAMAM nanocomposites had no significant cytotoxicity.

\section{Conclusion}

In summary, we have successfully synthesized dendrimer-modified CdTe nanocomposites. The CdTe-PAMAM nanocomposites retained the optical properties of the original QDs and they could pass through the cell membrane into the cell with excellent biocompatibility and low cytotoxicity, which may be useful for tracking cells and intracellular processes.

\section{Acknowledgment}

This work was supported by the Nature Science foundation of Hubei Province of China (2009CDB279) and the Scientific Research Foundation for the Returned Overseas Chinese Scholars, State Education Ministry.

\section{References}

1. Gaponik N, Talapin D V, Rogach A L, Hoppe K, Shevchenko E V, Kornowski A, Eychmüller A and Weller H, J Phys Chem B, 2002, 106, 7177-7185.

2. Michalet X, Pinaud F F, Bentolila L A, Tsay J M, Doose S, Li J J, Sundaresan G, Wu A M, Gambhir S S and Weiss S, Science, 2005, 307(5709), 538-544.

3. Costa-Fernández J M, Pereiro R and Sanz-Medel A, Trac-Trend Anal Chem., 2006, 25(3), 207-218.

4. Derfus A M, Chan W C W and Bhatia S N, Nano Lett., 2004, 4(1), 11-18.

5. Tomalia D A, Naylor A M and Goddard W A., Angew Chem Int Ed Engl., 1990, 29, 138-175.

6. Lee C C, MacKay J A, Fréchet J M J and Szoka F C, Nat Biotechnol., 2005, 23, 1517-1526.

7. Dufès C and Uchegbu I F, Adv Drug Deliver Rev., 2005, 57, 2177-2202.

8. Gillies E R and Fréchet J M, J Drug Discov Today., 2005, 10, 35-43.

9. Esumi K, Houdatsu H and Yoshimura T, Langmuir, 2004, 20, 2536-2538.

10. Zucolotto V, Gattás-Asfura K M, Tumolo T, Perinotto A C, Antunes P A, Constantino C J L, Baptista M S, Leblanc R M and Oliveira Jr O N, Appl Surf Sci., 2005, 246, 397-402.

11. Liu J A, Li H B, Wang W, Xu H B, Yang X L, Liang J G and He Z K, Small, 2006, 2, 999-1002.

12. Ying E, Li D, Guo S J, Dong S J and Wang J, PLoS One., 2008, 3(5), e2222. 


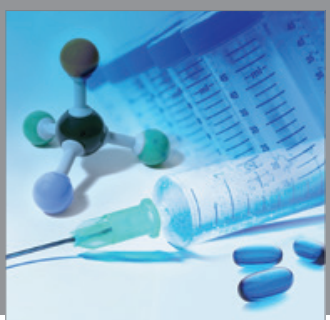

International Journal of

Medicinal Chemistry

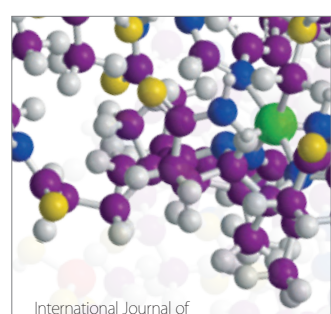

Carbohydrate Chemistry

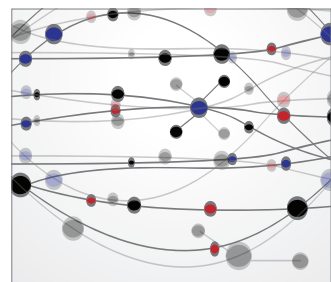

The Scientific World Journal
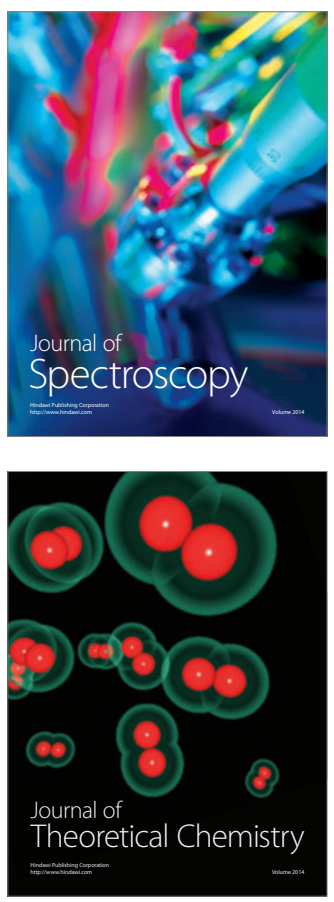
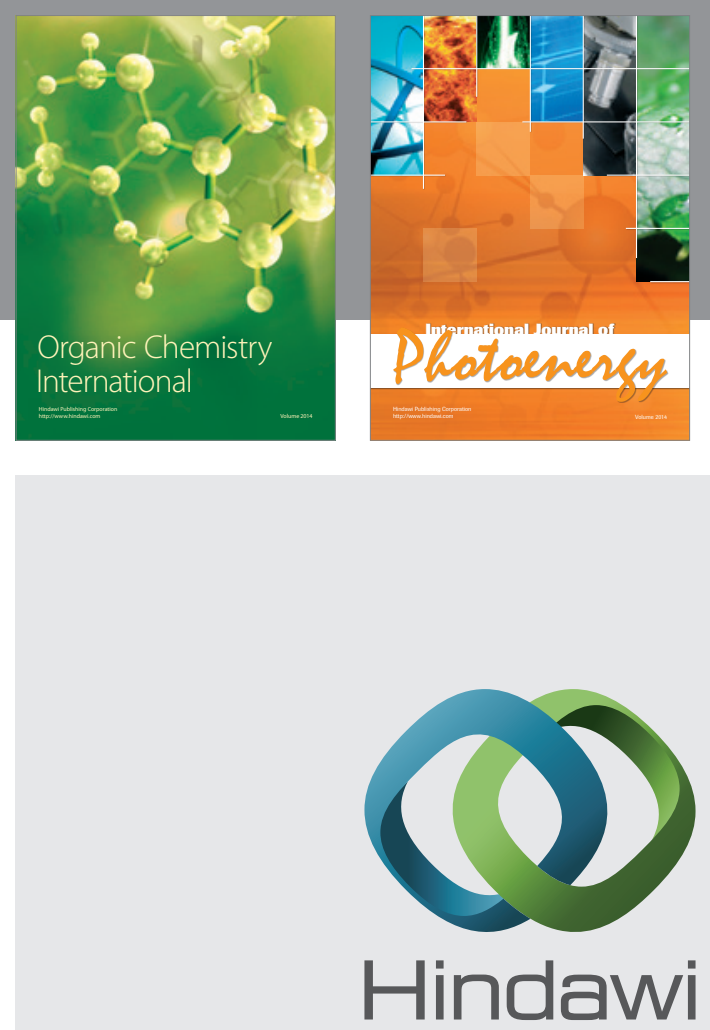

Submit your manuscripts at

http://www.hindawi.com
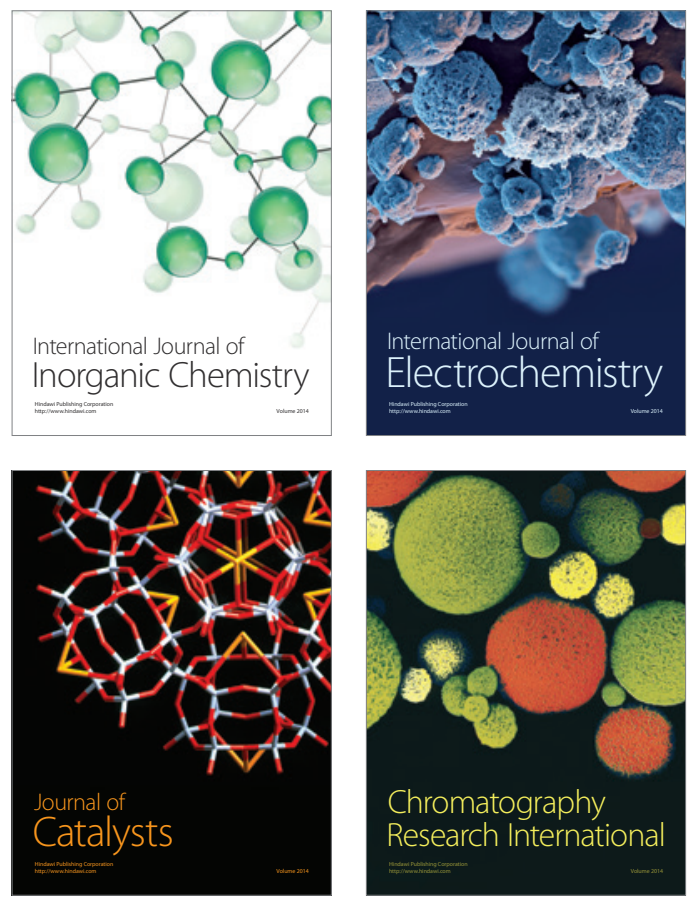
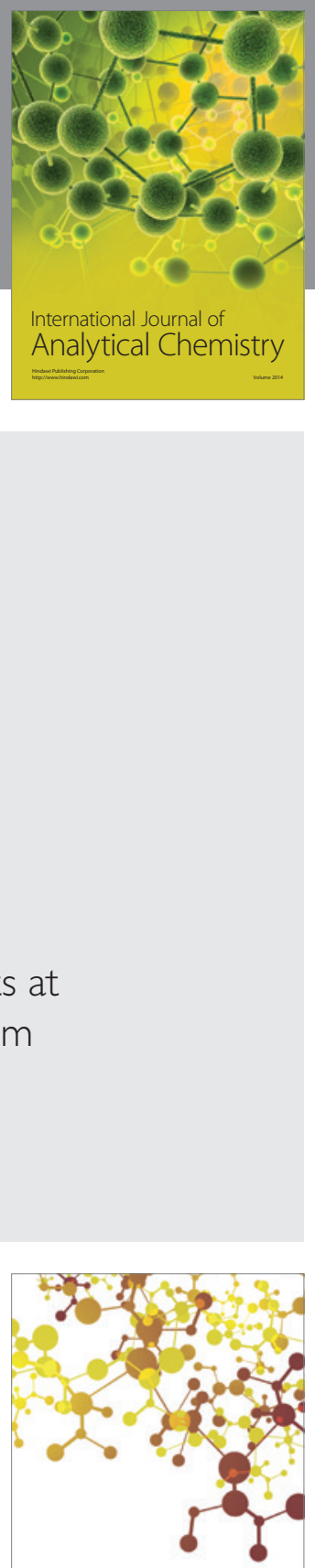

Journal of

Applied Chemistry
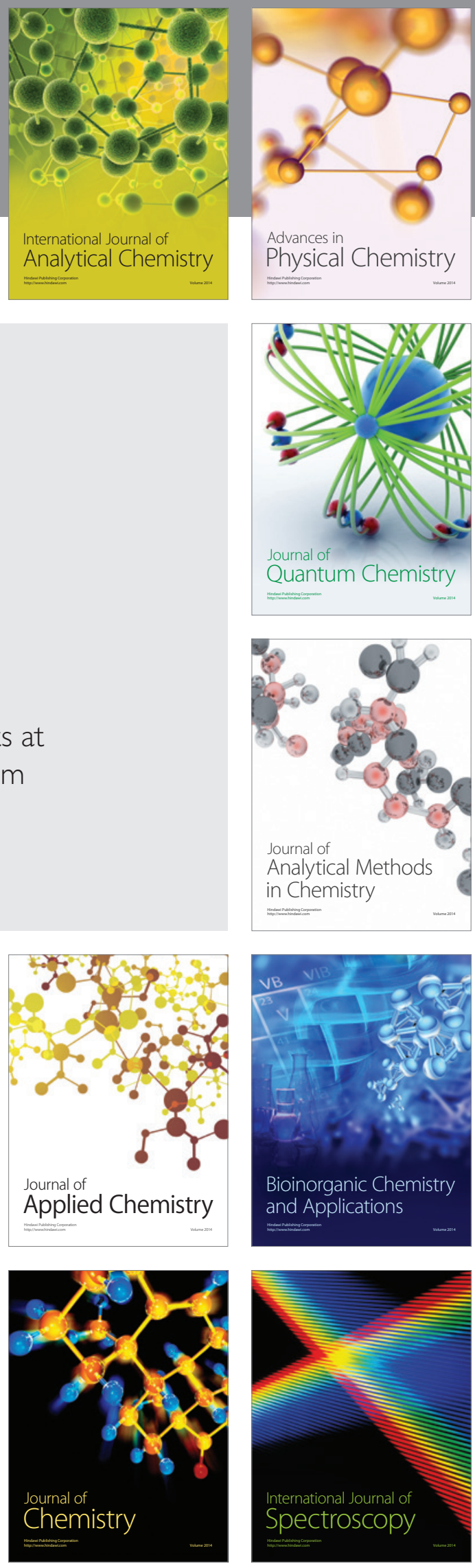